\title{
Organizations and Markets
}

\author{
Foss, Nicolai J.; Klein, Peter G.; Linder, Stefan
}

Document Version

Final published version

Publication date:

2013

License

CC BY-NC-ND

Citation for published version (APA):

Foss, N. J., Klein, P. G., \& Linder, S. (2013). Organizations and Markets. Institut for Strategic Management and Globalization. SMG Working Paper No. 8/2013

Link to publication in CBS Research Portal

\section{General rights}

Copyright and moral rights for the publications made accessible in the public portal are retained by the authors and/or other copyright owners and it is a condition of accessing publications that users recognise and abide by the legal requirements associated with these rights.

\section{Take down policy}

If you believe that this document breaches copyright please contact us (research.lib@cbs.dk) providing details, and we will remove access to the work immediately and investigate your claim. 


\section{ORGANIZATIONS AND MARKETS}

Nicolai J. Foss

Peter G. Klein

Stefan Linder

SMG WP 8/2013

April, 2013 
SMG Working Paper No. 8/2013

April, 2013

ISBN: 978-87-91815-90-4

Department of Strategic Management and Globalization Copenhagen Business School

Kilen, Kilevej 14A

2000 Frederiksberg

Denmark

www.cbs.dk/smg 


\title{
ORGANIZATIONS AND MARKETS
}

\author{
Nicolai J. Foss \\ Department of Strategic Management and Globalization \\ Copenhagen Business School \\ and Norwegian School of Economics \\ Kilevej 14A, $2^{\text {nd }} \mathrm{fl}$. \\ 2000 Frederiksberg, Denmark \\ njf.smg@cbs.dk \\ Peter G. Klein \\ Division of Applied Social Sciences \\ University of Missouri \\ and Norwegian School of Economics \\ 135 Mumford Hall \\ Columbia, MO 65211 USA \\ pklein@missouri.edu \\ Stefan Linder \\ ESSEC Business School \\ Avenue Bernard Hirsch, BP 50105 \\ 95021 Cergy-Pontoise (Paris), France \\ linder@essec.fr \\ Prepared for \\ Peter Boettke \& Chris Coyne (eds.), Oxford Handbook of Austrian Economics, \\ Oxford University Press.
}

Keywords: theory of the firm; firm boundaries; entrepreneurship; subjectivism; uncertainty, dispersion of knowledge, Austrian capital theory

JEL code: B53, D21, D23, D83 


\title{
Organizations and Markets
}

\begin{abstract}
Austrian economics focuses on markets, but has much to say about organizations. In particular, Austrian insights on the structure of production, the heterogeneity and subjectivity of resources, the nature of uncertainty, the role of monetary calculation, and the function of the entrepreneur provide solid foundations for a distinctly Austrian theory of organizations. We review these insights, discuss recent literature on Austrian economics and the theory of the firm, and suggest new directions for developing and extending an Austrian approach to organizations.
\end{abstract}




\section{INTRODUCTION}

Austrian economics deals primarily with markets, focusing on production, exchange, and consumption by individuals interacting in commercial markets characterized by private property, monetary calculation, and the price mechanism-what Mises (1949) called "catallactics." Of course, Austrians have also dealt with socialism (Mises, 1920, 1922; Rothbard, 1976; Lavoie, 1985), interventionism (Mises, 1928; Rothbard, 1970; Ikeda, 1997), law (Hayek, 1960, 1978), and other institutions (Menger, 1883), mainly to enhance our understanding of market exchange. Austrians have devoted less attention to the internal working of voluntary, private organizations such as families, clubs, and business firms, where resources are allocated by fiat or consensus, rather than monetary exchange. Like their neoclassical counterparts Austrians have, until recently, been reluctant to open up the "black box" of the organization.

Austrian theory suggests that organizations, as with the Crusoe economy or cottage production, are inherently disadvantaged relative to market systems where a complex division of labor is needed because they lack the alienable property rights and internal price system needed to facilitate monetary calculation (Klein, 1996). Moreover, organizations encounter the problem faced by any planned order, namely that the "organizer must wish the individuals who are to cooperate to make use of knowledge that he himself does not possess" (Hayek, 1973: 49). Yet, organizations - collectives aimed at achieving specific goals (Parsons, 1956)-are ubiquitous parts of market economies, possibly even the dominant features of the economic landscape (Simon, 1991).

Why, given what Hayek called the "marvel" of market coordination, do organizations large and small emerge and persist? How do they avoid the problem of economic calculation faced by socialist economies? Why do organizations take the shapes they do, why do their characteristics vary over time and across industries, and why do they succeed or fail? Are most organizations 
stable over time, or do organizations, like markets, adapt and learn? How do entrepreneurs arrange assets and manage individuals within organizations? These and similar questions are key to an understanding of both organizations and markets. Yet, while Austrian economists have studied institutions and theorized about the organization of economic activities (Langlois, 1992), a stream of literature on a "theory of the firm" building on distinctly Austrian assumptions and insights has emerged only recently.

The modern economic theory of the firm is usually traced to Ronald Coase's seminal 1937 article and the classic contributions in the 1970s from Williamson (1971, 1975, 1979), Alchian and Demsetz (1972), Jensen and Meckling (1976), Klein, Crawford, and Alchian (1978), and others. As we argue below, key insights from this field also appear in the Austrian literature (Foss, 1994; Klein, 1996; Foss and Klein, 2010); in many cases, Austrian insights not only precede (Foss, 1994), but also challenge modern organizational economics and provide solid foundations for a distinctly Austrian theory of organizations that overcomes weaknesses in the standard treatments. ${ }^{1}$ In particular, the Austrian understanding of heterogeneous, subjectively perceived, capital resources, Mises's (1920) contribution on the calculation problem of socialist economies, Hayek's (1937, 1945) work on dispersed knowledge and the problem of coordination, Rothbard's (1962) generalization of Mises' insights to the case of large firms, and the longstanding Austrian emphasis on the entrepreneur as a causal agent provide the foundations for a full-fledged theory of organizations in general and firms in particular.

\footnotetext{
${ }^{1}$ By "modern organizational economics" or the "modern theory of the firm" we mean primarily agency theory, transaction cost economics, mechanism design, incomplete-contracting theory, and other approaches surveyed, for example, in Gibbons and Roberts (2012). In this chapter we ignore the relationship between Austrian economics and other approaches to the firm that dominate the strategic management literature, such as the resource-based and capabilities approach. On resources and capabilities see Foss (1997), Langlois (1992), Foss, Foss, Klein and Klein (2007), and Foss and Ishikawa (2007). Like Austrian economics, resource-based and capabilities approaches stress the heterogeneity of capital assets and the benefits of combining them in complementary bundles that generate competitive advantage.
} 
Drawing on earlier work such as Foss $(1994,1997)$, Klein $(1996,1999)$ and Foss and Klein (2010, 2012), we discuss these key Austrian insights and how they allow building a promising Austrian theory of the firm. We subsequently discuss attempts within AE to build such a theory and present the judgment-based approach proposed recently by Foss and Klein (2012). While we focus on firms, the subsequent discussion bears implications for research on organizations more generally; all organizations are challenged by dispersed knowledge and genuine uncertainty, and all of them need to allocate resources in the context of heterogenous capital assets and partly missing markets. Thus, while we refer to profit-seeking organizations (i.e., firms) in the following, most of the discussion applies to public non-profit organizations as well.

\section{THINKING ABOUT ORGANIZATIONS}

What is usually termed the "neoclassical" theory of the firm emerged in the 1920s and 1930s in the works of Pigou (1928), Viner (1931), and Robinson $(1933,1934)$ as a parallel effort to the formalization of consumer theory (Hicks and Allen, 1934; Loasby, 1976). In many economics textbooks the "firm" is portrayed as a production function or production possibilities set, a black box that transforms inputs into outputs. The firm is modeled as a single actor, solving a maximization problem completely analogous to the problem facing the utility-maximizing consumer. How production is organized - for example, whether inputs $x_{1}, x_{2}$, and $x_{3}$ are combined into output $y$ within a single firm, between partners, across a network of independent contractors, or by some other means-is treated as secondary, even trivial, issue with little consequence for resource allocation.

Coase (1937) introduced a fundamentally different way to think about production and the firm. In the world of neoclassical price theory, he noted, firms have no reason to exist. If firms emerge in a market economy, he reasoned, it must be that there is a "cost to using the price 
mechanism" (Coase 1937: 390). Market exchange entails certain costs, such as identifying trading partners, negotiating terms, and writing and enforcing contracts. Inside a firm, the entrepreneur may be able to reduce these "transaction costs" by coordinating these activities himself. However, internal organization brings other kinds of transaction costs, namely problems of information flow, incentives, monitoring, and performance evaluation. The boundary of the firm, then, is determined by the tradeoff, at the margin, between the relative transaction costs of external and internal exchange. ${ }^{2}$

Modern, post-Coasean theories of the firm such as transaction cost economics (TCE) (Williamson, 1971, 1975, 1985; Klein, Crawford, and Alchian, 1978) and the incompletecontracting or "property rights" approach (PRT) (Hart, 1995), as well as the nexus-of-contracts view, (Alchian and Demsetz 1972), agency theory (Ross 1973; Jensen and Meckling, 1976), and team theory (Marschak and Radner 1972), follow Coase in seeing the firm as a contractual entity whose existence and characteristics are shaped by transaction costs or information costs. ${ }^{3}$ Of course, each theory asks somewhat different questions and invokes particular kinds of transaction or information costs to give the answers (Gibbons, 2005). Principal-agent models and team theory are interested mainly in internal organization and emphasize monitoring costs, while TCE and PRT deal with firm boundaries and highlight costs of writing (complete) contracts or the ex post costs of enforcement and renegotiation.

\footnotetext{
${ }^{2}$ An earlier tradition approached the distinction between firm and market in terms of the relative intensities of the division of labor, but this tradition was ignored by Coase, and largely forgotten after Coasean insights began to take hold (Bylund, 2011).

${ }^{3}$ Only transaction cost economics and the incomplete-contracting approach are theories of the firm per se (Hart, 1995). Nexus-of-contracts, principal-agent and team theories deal with productive relationships, but do not address asset ownership; that is, they do not talk about the boundaries of the firm. To explain boundaries, one must presuppose that contracts are incomplete, for otherwise everything can be stipulated contractually and there is no need for ownership, understood as the "residual right" to make decisions that are not specified by contract. Team theory and principal-agent models assume complete contracts, whereas transaction cost economics and property rights theory work from an incomplete contracting foundation.
} 
Still, all branches of modern organizational economics reject some or all aspects of the perfectly competitive general equilibrium model, starting with Coase and Williamson and including modern contract theory (Salanié, 1997; Laffont and Martimort, 2002). ${ }^{4}$ Complications such as (genuine) uncertainty (Knight, 1921), imperfect foresight or bounded rationality (Coase, 1937; Kreps, 1996; MacLeod, 2002), small-numbers bargaining (Williamson, 1996), haggling costs (Coase, 1937), private information (Holmström, 1979), cost of processing information (Marschak and Radner, 1972; Bolton and Dewatripont, 1994), costs of inspecting quality (Barzel, 1982, 1997), or imperfect legal enforcement (Hart, 1995; Williamson, 1996), are all deviations from the full, complete, contingent contracting model of perfectly competitive general equilibrium theory (Debreu, 1959).

Post-Coasean theories of the firm have greatly enhanced our understanding of firms as contractual entities whose existence, boundaries, and internal organization can be rendered intelligible in terms of economizing on (various types of) transaction costs. Yet, numerous issues have remained unaddressed by modern economics thinking on organizations. Consider the following questions.

1. What is a firm, exactly? Coase (1937) defines the firm in terms of the employment relation. A one-person operation, in this definition, is not a firm, and vertical integration deals with the question of adding producers of intermediate products to the firm's employment roll. For Knight, Williamson, and Hart, in contrast, the firm is defined not by the employment relationship, but by the ownership of alienable assets. In this approach, the question is who owns what, not who is employed by whom. ${ }^{5}$ Knight, for example, begins with judgment, defined as

\footnotetext{
${ }^{4}$ The rejection is clearly spelled out in Knight (1921), though Knight did not develop a systematic theory of the firm.

${ }^{5}$ Spulber (2009) offers yet another approach, defining the firm as nexus of transactions with objectives different from those of its owners.
} 
business decision making when the range of possible future outcomes, let alone the likelihood of individual outcomes, is generally unknown - what he termed uncertainty (or uninsurable risk), rather than probabilistic (or insurable) risk. To exercise judgment, the entrepreneur must own and control resources, which are then deployed under conditions of uncertainty. The firm is then the entrepreneur plus the assets he owns and controls (Foss and Klein, 2012). Of course, even in this approach, to get from the one-person firm to the multi-person firm requires some theory about the relative transaction costs of employment versus independent contracting (we discuss this issue later).

Perhaps the better question than "what is a firm" is "what are the important research questions that can be answered when the firm is defined in a particular way?"

2. Why do firms differ, and why does it matter $?^{6}$ Despite moving beyond neoclassical notions of the "representative firm," some branches of modern organization economics remain committed to explaining equilibrium configurations populated by optimizing agents. And yet, most industries are characterized by wide variation in firm performance (e.g., Cool and Schendel, 1988; Porter, 1979). Why some firms earn superior returns has been the area of key interest among strategic management scholars (Grant, 1996), yet received little attention in the established economics thinking on organizations.

Inter-firm performance differences is the central explanandum of strategic management theory, which relates these differences to heterogeneous resources or differential capabilities of firms (e.g., Winter, 1988; Langlois, 1992; Kogut and Zander, 1992; Jacobides and Winter, 2005). Strategy research describes firm-specific knowledge as sticky and tacit and argues that such knowledge develops through path-dependent processes, implying that organizations are

\footnotetext{
${ }^{6}$ Nelson (1991) poses the question in exactly this form.
} 
necessarily limited in what they know how to do well. ${ }^{7}$ Such an emphasis on knowledge contrasts sharply with the organizational economics focus on incentives, opportunism, and transaction costs. While much of the modern theory of the firm treats knowledge needed for exchange as costly, it treats the knowledge needed for production as essentially free (Demsetz, 1988). The strong emphasis on transaction costs "dims our view of the full picture by implicitly assuming that all firms can produce goods or services equally well" (Demsetz, 1991: 164). However, it might be in the interest of a firm to produce its own inputs even if transaction costs were zero and costs of in-house managing were positive, if firms differ in how well they can do production (ibid.).

Low-cost methods of production have to be "discovered anew, sometimes almost from day to day, by the entrepreneur" (Hayek, 1940: 196). The dispersion of knowledge (Hayek, 1945) and the idiosyncratic nature of much of the economically relevant knowledge (Hayek, 1935b), the distribution of entrepreneurial capabilities (Knight, 1921) or the benefits of specialization imply that organizations will differ in how well (or how cost efficient) they can produce or provide their offerings. Hence, besides transaction costs, the production costs may enter the make-or-buy decision, i.e. the question about the boundaries of the firm (Foss, 1994).

There have been several attempts at integrating transaction cost and capabilities approaches to the firm (surveyed in Argyres, Felin, Foss and Zenger, 2012) Argyres and Zenger (2012) argue, for example, that transaction costs and property rights govern how capabilities are

\footnotetext{
${ }^{7}$ There are important connections between capabilities and knowledge-based views and Austrian ideas about tacit knowledge. Not surprisingly, several Austrian writers have been particularly attracted to the knowledge-based view as it appears to take seriously the Hayekian notions of tacit, dispersed knowledge and rule-following behavior (Malmgren 1961; O'Driscoll and Rizzo 1985; Loasby 1991; Langlois 1992, 1995, 1998; Foss 1997, Foss and Christensen 2001; Dulbecco and Garrouste 1999). Exploring the Austrian roots of capabilities theory has become a virtual cottage industry in recent years. The connection between Penrose and the Austrian school—both indirect and directly through Penrose's dissertation advisor, Mises student Fritz Machlup - has also been examined (Connell, 2007; Foss, Klein, Kor, and Mahoney, 2008). However, these explorations have produced few distinctive insights and refutable implications, limited mainly to exploring similarities between the two bodies of thought.
} 
generated and transmitted. On the whole, however, these branches of literature remain distinct. Austrian economics certainly recognizes performance differences among firms but, rejecting the perfectly competitive model as a market benchmark, does not see deviations from "normal" profits as a particularly interesting or important phenomenon to be explained. Austrians view profit as an amount (revenues less costs), not a rate of return, and Austrian concepts of competition leave no room for a normal rate of profit that firms try to exceed.

3. How do organizational forms emerge, and what determines their survival? A given transaction may be organized in different ways such as arms-length market exchange, internal production, and intermediate forms like franchising agreements and joint ventures. However, the range of possible forms is typically given in modern organizational economics to the decision maker, there is no uncertainty about them, and there is no room for organizational innovation and entrepreneurship.

Williamson, for example, takes as a heuristic starting point that "in the beginning there were markets" (Williamson, 1985: 142). Since markets are given, so are also inputs, outputs, and technology. As it is the case with the nexus-of-contracts approach, the agents that occupy Williamson's attention are managers of existing transactions, shifting transactions over the boundaries of the firm. He thus does not address questions of innovation and the creation of markets (Williamson 1985). Introduction of new types of governance modes is "outsourced" to an essentially unspecified external mechanism and equally essentially unspecified selection forces are presumed to select the fittest/most efficient (or fitter/relatively more efficient) of these contracts or organizational forms (Foss, 1997). However, a complete theory of organizations should account for the emergence and diffusion of organizational forms (James, Klein, and Sykuta, 2011). 
4. What explains change in organizational boundaries? Established economics thinking about organizations readily allows firm size to be affected by innovations, such as the telephone, or other communication media, that change the relative costs of market- vs. in-house transactions (Coase, 1937). Yet, just as for the emergence of new governance modes, it leaves the source of and drivers behind the innovation in the dark, i.e. innovations are exogenous events to which firms simply adapt by shifting their boundaries inwards or outwards. Modern theories of the firm, in the tradition of Schumpeter (1911) often resort to a "deus ex machina" that introduces new innovations affecting transaction costs and firm sizes.

The highly prosperous cottage industry working on innovative management accounting practices, such as, for example, the Balanced Scorecard, Activity-based Costing, Activity-based Budgeting, new ERP systems, and so on, suggests that firms engage (and are willing to spend considerable resources) in developing and introducing innovative practices that facilitate cost allocations, internal calculations of unit and product profitability, and resource allocation processes. Thus, a theory of the firm should at least partially endogenize the development of innovations affecting firm size and scope.

5. Do organizations learn? Firm boundaries change frequently, in ways that are difficult to explain within an equilibrium, comparative-static framework. In other words, firms adjust their behavior even in the absence of changes in technology, institutions, or market conditions. Firms regularly acquire other firms and divest parts of their current business. While part of this M\&A activity likely is a response to new governance modes and new innovations that change the relative transaction costs of using the market versus exchanging the service/good internally, a significant part takes place without changes in transaction costs, and can be understood as a 
process of experimentation and learning (Klein and Klein, 2001; Lien and Klein, 2013). Still, much of the extant literature focuses on equilibrium, "optimal" contracts.

Agency theory, for example, assumes that the roles of principal and agent are already assigned, that principals know the full set of possible actions the agent can take, and that all contracting is efficient on an ex ante basis, meaning that all gains from trade have been discovered and that no reallocations of property rights during later stages need to occur. In the real world of dispersed knowledge and uncertainty, this kind optimality cannot be assumed; as Loasby (1992: 140) puts it, "all perceived gains from trade are realized; but there may be gains that are not perceived, simply because the attempts to carry out plans do not bring them to anyone's attention." Hence principals may be surprised, leaving room for Kirznerian discovery (Kirzner 1973) or Knightian judgment (Knight, 1921).

Transaction cost economics does allow for novelty and genuine surprise, captured by the notion that all real-world contracts are incomplete. Even in this case, however, participants are assumed to have "correct" knowledge about fundamental market conditions, such as the likelihood of potential holdup (Foss, 1994). Hence there is no need to change a firm's boundaries in the absence of changes in transaction costs-the "right" boundaries were chosen ex ante. Reports about firm's M\&A activities and reasons for divestures, however, suggest that firms infact commit errors and see a need for ex post adaptation of their boundaries (Klein and Klein, 2001).

6. Is entrepreneurship a factor of production? When explaining the returns to factors of production economists often define wages as the payment to labor, interest as the payment to capital, rent as the payment to land, and profit as the payment to entrepreneurship. Treating entrepreneurship as a factor of production, earning a return we label profit, poses some 
challenging problems, however. Does entrepreneurship have a marginal revenue product, corresponding to a firm's profit? Is there an upward-sloping supply curve for entrepreneurship (more of it is offered to the market when profits rise)? Are there diminishing returns to entrepreneurship?

The answer given by the classic contributors to the economic theory of entrepreneurship such as Cantillon, Say, Schumpeter, Knight, Mises, Kirzner, and others is clearly no. They treat entrepreneurship as ubiquitous, an attribute of the market mechanism that can never be absent. This perspective is neatly summarized by Marchal (1951: 550-551; emphasis added):

[E]ntrepreneurs obtain remuneration for their activity in a very different manner than do laborers or lenders of capital. The latter provide factors of production which they sell to the entrepreneur at prices which they naturally try to make as high as possible. The entrepreneur proceeds quite otherwise; instead of selling something to the enterprise he identifies himself with the enterprise. Some people doubtless will say that he provides the function of enterprise and receives as remuneration a sum which varies according to the results. But this is a tortured way of presenting the thing, inspired by an unhealthy desire to establish arbitrarily a symmetry with the other factors. In reality, the entrepreneur and the firm are one and the same. His function is to negotiate, or to pay people for negotiating under his responsibility and in the name of the firm, with two groups: on the one hand, with those who provide the factors of production, in which case his problem is to pay the lowest prices possible; on the other hand, with the buyers of the finished products, from which it is desirable to obtain as large a total revenue as possible. To say all this in a few words, the entrepreneur, although undeniably providing a factor of production, perhaps the most important one in a capitalist system, is not himself to be defined in those terms.

Entrepreneurship, in this sense, is embodied in the firm; the decision to be "entrepreneurial" is not a marginal decision, in the sense of supplying one more or one less unit 
of entrepreneurial services to the firm. ${ }^{8}$ Writing of socialism, fascism, and other forms of government intervention in the economy, Mises (1949) describes the struggle of business owners to operate in deteriorating political circumstances. Despite the threat of expropriation and other hazards, entrepreneurs will continue to act. "In the market economy there will always be entrepreneurs. Policies hostile to capitalism may deprive the consumer of the greater part of the benefits they would have reaped from unhampered entrepreneurial activities. But they cannot eliminate the entrepreneurs as such if they do not entirely destroy the market economy" (Mises, 1949: 291). As long as there is private ownership, markets, and prices, there is entrepreneurship - regardless of the numbers of start-ups, patents, and the like.

Part of the reason economists speak of the supply of entrepreneurship and the marginal return to entrepreneurship is that they conceive entrepreneurship as an occupational category such as self-employment. An entrepreneur is a person who starts his own business, as opposed to an employee who works for someone else. In this sense it makes sense to talk about entrepreneurship as a factor of production with an upward-sloping supply curve. As profit opportunities increase, relative to wages, more individuals will choose self-employment over employment. If one conceives entrepreneurship as a function such as alertness, cognitive leadership or judgment, however, it cannot be treated as a factor of production and is exercised, as in the Mises quote above, even in the worst market conditions.

7. How do organizations influence the institutional environment? Established thinking on organizations typically takes the institutional environment-legal rules, political processes, social norms, and the like — as given, asking how firms try to make profits within the constraints established by these rules of the game. Changes in macro-level institutions are viewed as shocks,

${ }^{8}$ Menger's (1871) treatment of the entrepreneur is similar: "The activity of the entrepreneur is recognized by Menger as being unique in that, unlike other goods of higher order, it is not intended for exchange and therefore does not command a price" (Martin, 1979: 279-280). 
or "shift parameters" (Williamson, 1996: 326), that affect the efficient boundary between one organizational form and another. But the institutional environment is not fixed, and efforts to influence legal, regulatory, political, and social conditions may be as important to firms as efforts to influence their competitive and technological environments (Moore et al., 2012; Oh \& Oetzel, 2011). Firms seek to influence legal, regulatory, and political institutions through lobbying, rentseeking, and other activities (Bonardi, Hillman \& Keim, 2005; Garud, Hardy \& McGuire 2007, Klein, et al., 2010). A complete theory of organizations, and of the boundaries between organizations and markets, must take into account the fundamental endogeneity of institutions, and the co-evolution of organizational and market characteristics.

The shortcomings of established economic thought on organizations suggest that we need to look for models that allow us to answer the same fundamental questions while also being able to circumvent or at least minimize the shortcomings identified. As we demonstrate in the subsequent sections, key Austrian insights on production processes and the nature of capital goods, dispersed knowledge, uncertainty, and entrepreneurship provide a promising avenue for such a venture.

\section{AUSTRIAN CAPITAL THEORY AND THE THEORY OF ORGANIZATIONS}

\section{Austrian capital theory}

Austrian production theory starts with the insight that production takes time and, in an advanced industrial economy, typically involves a series of temporally specific, causally linked stages and a complex latticework of inputs and intermediate outputs (Menger, 1871). This has two implications: First, factors of production must be committed in the present for making final goods that will have value only in the future after they are sold (e.g., Hayek, 1931a). As a consequence, from the time the decision is made to use the factors of production to when the 
final good has been finished, the entrepreneur's judgment about market demand and prices for the final good may turn out to be flawed. Entrepreneurs pay today's certain prices for factors, but cannot be sure whether they will realize the expected value of the final goods in the future. Second, as capital goods are used in production, they are transformed from general-purpose materials and components to intermediate products specific to particular final goods. Consequently, these assets cannot be easily redeployed to alternative uses if demands for final goods change (Lachmann, 1956). Metal stamped into part of a chassis of a Ferrari likely cannot be directly redeployed to the chassis of a Freightliner or other brand of heavy truck, or used to make a toaster, or used to thresh wheat. This is particularly true for the capital goods that are in later stages of the production process because they are typically already more specific to a particular end use and thus more difficult to convert. The claim is not that there is no substitution among capital goods, but that the degree of substitution is limited (i.e. capital goods are considered as multi-specific). Because capital is heterogeneous, production cannot be adequately described by the stylized production function - a "black box" transforming in one single stage inputs (land, labor, capital) into output (consumer goods)—favored by neoclassical economists.

This heterogeneity of capital assets stems, as modern Austrian economics (AE) points out (e.g., Kirzner, 1966), from the entrepreneurs' subjective, individual production plans - plans that are formulated and continually revised by profit-seeking entrepreneurs. Instead of characterizing capital goods by their physical properties as earlier Austrian scholars attempted do (e.g., BöhmBawerk, 1959), modern AE proposes to rely on their place in the structure of production as conceived by entrepreneurs. The actual place of any capital good in the time sequence of production is given by the market for capital goods, in which entrepreneurs bid for factors of production in anticipation of future consumer demands. This subjectivist, entrepreneurial 
approach to capital assets is particularly congenial to theories of the firm that focus on entrepreneurship and the ownership of assets (Foss and Klein, 2012).

This understanding of capital as a complex structure formed the basis of the Austrian theory of the business cycle (Mises, 1912; Hayek, 1931a), which highlights the role of malinvestments. The concept of "malinvestment" is foreign to neoclassical production theory (as well as mainstream macroeconomics), which usually considers only the level of investment. Modern production theory focuses on a single stage of production in which "capital," along with other inputs, is transformed into final goods. As we argue next, this limits the explanatory power of theories, such as modern macroeconomics, that are based on this conception of capital.

\section{Implications of Capital Heterogeneity for the Theory of Organizations}

If capital is a homogeneous substance with one price, then entrepreneurship is reduced to choosing between capital-intensive and labor-intensive production methods (or among types of labor), a problem a central planner could potentially solve. The failure of socialism, in Mises's (1920) formulation, follows precisely from the complexity of the economy's capital structure, and the subsequent need for entrepreneurial appraisal. As Lachmann (1956: 16) points out, entrepreneurship consists primarily of choosing among combinations of capital assets: "We are living in a world of unexpected change; hence capital combinations . . . will be ever changing, will be dissolved and reformed. In this activity, we find the real function of the entrepreneur." Attributes may also vary over time, even for a particular asset. In a world of "genuine" uncertainty, entrepreneurs are unlikely to know all relevant attributes of all assets when production decisions are made. Nor can the future attributes of an asset, as it is used in production, be forecast with certainty. Future attributes must be discovered over time, as assets 
are used in production. Therefore, capital heterogeneity has several important implications for economic organization (Foss and Klein, 2012).

First, capital heterogeneity implies the need for monetary calculation in the formulation of entrepreneurial plans. If each capital good is perfectly specific to just one final good, then the valuation of consumer goods directly allows valuing the capital goods. Yet, if capital is heterogeneous, but multi-specific (Lachmann, 1956) — that is, if some substitution can take place at a certain cost - then we need markets in which these capital goods are traded to have indications of relative scarcity and to be able to evaluate economically alternative plans for using capital goods. In general, the calculation problem highlighted in the socialist calculation debate waged by the Austrians in the 1920s and 1930s (e.g., Mises, 1920, 1936) is not about socialism per se, but the results of the heterogeneous, yet multi-specific nature of capital assets.

Second, because it is difficult, or perhaps even impossible, to specify all relevant attributes of an asset ex ante, ownership rights are assigned to assets, not their attributes. Ownership of an asset gives the owner the rights to exploit attributes unknown at the time ownership rights are conferred. When firms are defined in terms of asset ownership, this entrepreneurial perspective helps explain the boundaries of the firm. Third, because attributes of assets are costly to measure, and often unknown even to their owners, entrepreneurs must often experiment with different combinations of capital goods.

Finally, the entrepreneur's success in experimenting with assets in this manner depends not only on his ability to anticipate future prices and market conditions, but also on internal and external transaction costs, the entrepreneur's control over the relevant assets, how much of the expected return from experimental activity he can hope to appropriate, and so on. Thus, entrepreneurs who seek to create or discover new attributes of capital assets will want ownership 
titles to the relevant assets, both for speculative reasons and for reasons of economizing on transaction costs.

These implications already suggest some preliminary answers for questions about why firms exist and what determines their boundaries. They thus suggest that the Austrian theory of production may be a fruitful starting point for building a "good" theory of organizations.

\section{AN AUSTRIAN THEORY OF ORGANIZATIONS?}

While until recently, the theory of the firm did not attract much attention in AE, the last two decades have seen a number of publications emerging that develop elements of a distinctly Austrian theory of the firm (e.g., Dulbecco and Garrouste, 1999; Foss, 1994; Foss, Foss, Klein, Klein, 2007; Foss and Klein, 2012; Iaonnides, 1998; Klein, 1996; Lewin and Phelan, 2000). The Austrian emphasis on subjective knowledge, skills, beliefs, expectations, and mental models is a central element in these steps towards building an Austrian theory of the firm. Together with the Austrian focus on process analysis, subjectivism and uncertainty open the door to address entrepreneurship - the arguably most neglected Austrian concept within the contemporary theory of the firm — and to build a theory of the firm around it (Dulbecco and Garrouste, 1999). While Austrians agree on the central role of entrepreneurship for an Austrian theory of the firm, there is some disagreement about how to characterize entrepreneurship for this purpose. This disagreement has led scholars to pursue different routes for developing elements of an Austrian theory of the firm.

The best-known perspective on entrepreneurship is Kirzner's (1973, 1979, 1992) identification of entrepreneurship with alertness to profit opportunities. The simplest case of alertness is that of the arbitrageur, who discovers a discrepancy in present prices that can be exploited for financial gain. In a more typical case, the entrepreneur is alert to a new product or a 
superior production process and steps in to fill this market gap before others. Success, in this view, comes not from following a well-specified maximization problem, but from having some insight that no one else has, a process that cannot be modeled as an optimization problem. Because Kirzner's entrepreneurs perform only a discovery function, rather than an investment function, they do not need to own capital; they need only be alert to profit opportunities. They own no assets, they bear no uncertainty, and hence they cannot earn losses-the worst that can happen to an entrepreneur is the failure to discover an existing profit opportunity.

Several scholars have worked on developing a theory of the firm based on Kirzner's conception of entrepreneurship (e.g., Ioannides, 1998; Sautet, 2010). At the same time, Kirzner's view on entrepreneurship has been the object of much critical debate. Loasby (1992: 143), for example, claims that "Kirzner has also accepted the neoclassical view of knowledge as 'information,' which is not merely inadequate but false. For many simple entrepreneurial perceptions, the falsity of this view does not matter, but for more complex opportunities of arbitrage [...] it may be important." Rothbard (1985) and Salerno (1990, 2008), in turn, question Kirzner's purely alert entrepreneur as neglecting the importance of assets for exploiting entrepreneurial opportunities and thus also criticize him for misreading Mises and Hayek, whose position on entrepreneurship is rather one about economic calculation and (price) coordination than of alertness and discovery and who stress the importance of asset ownership. Even the arbitrageur - to use the simplest examples of the Kirznerian entrepreneur-needs some funds (or at least control over them) to acquire the assets that are undervalued at one location before being able to sell them off at a profit in another location. Without these funds the arbitrageur may well identify an entrepreneurial opportunity, but may not be able to realize it — or, when sharing his ideas with potential not-penniless others, have problems appropriating (a part of) the profit. 
If the Kirznerian entrepreneur shares his discovery with others in order to convince them to provide him with their funds for realizing his entrepreneurial opportunity, they may simply go about realizing his idea without him as the opportunity now is known to them and as the only alert, but penniless entrepreneur lacks bargaining power. The link between Kirznerian entrepreneurship and other branches of economic analysis, such as industrial organization, innovation, and the theory of the firm, is thus weak. As a consequence, progress towards a fully fledged theory of organizations based on Kirzner's concept has been slow.

Another approach, advanced by Witt (1998, 1999), focuses not on alertness, but on coordination via cognitive leadership. Entrepreneurs, Witt argues, require complementary factors of production, which are coordinated within the firm. For the firm to be successful the entrepreneur must establish a tacit, shared framework of goals-what Casson (2000) calls a "mental model" of reality—which governs the relationships among members of the entrepreneur's team (Witt, 2007). As Langlois (1998) points out, it is often easier (less costly) for individuals to commit to a specific individual, the leader, rather than an abstract set of complex rules governing the firm's operations. Exercising charismatic authority in an appropriate manner, then, facilitates coordination within organizations (Witt, 2003). It allows benefiting from autonomous motivation (aka: intrinsic motivation), which would not be possible using a market setting where extrinsic motivation, and in particular: monetary motives, is the sole driver (Witt, 2007). Cognitive leadership, thus, following him, provides a rationale for the multi-person firm (ibid.). Building on self-determination theory from social psychology, Witt (2007), however, is careful to highlight the danger of a potential crowding-out of employees' autonomous motivation by the entrepreneur's monitoring and incentivizing practices. The appropriate design of the firm's internal organization to leave "the employees room for own initiative and creative 
problem solving" (Witt, 2007: 1137), thereby fostering high effort based on autonomous motivation, hence is a centerpiece for benefiting from the advantage firms as institutional arrangements can offer to entrepreneurs above what markets can.

Witt's cognitive leadership approach to the firm thus combines insights from economics, psychology, and sociology. Leaders coordinate through effective communication, not only of explicit information, but also tacit knowledge - plans, rules visions, and the like (Witt, 2003). The successful entrepreneur excels at communicating such models. In Witt's proposal for an Austrian theory of the firm, as in Coase (1937), the employment relationship is central to the theory of the firm. The entrepreneur's primary task is to coordinate the human resources that make up the firm. Consequently, Witt's approach explains the dynamics among team members but does not necessarily provide an answer to the questions of whether the charismatic leader necessarily needs to own physical capital or why charismatic leadership should be regarded as more "entrepreneurial" than other, comparatively mundane managerial tasks such as structuring incentives, limiting opportunism, administering rewards, and so on. By leaving open the question of how the entrepreneur gets the requisite assets, Witt's approach runs the risk of being criticized for the same issue as approaches, such as by Iaonnides (1998), that build on Kirzner's alert but penniless entrepreneur: how does the entrepreneur convince asset owners - given dispersion of knowledge and genuine uncertainty hampering communication and rendering entrepreneurship not a normal factor of production - to provide the capital necessary to implement her/his vision (or perceived business opportunity) or by which way the entrepreneur goes about implementing those visions or opportunities requiring assets for exploitation and not only ideas or alertness.

Exercising judgment in a world of uncertainty is a third Austrian perspective on entrepreneurship that is associated mainly with Knight (1921) and Mises (1949). As noted above, 
judgment refers primarily to business decision making when the range of possible future outcomes, let alone the likelihood of individual outcomes, is generally unknown. Decisionmaking about the future thus relies on a kind of understanding that is subjective and tacit, one that cannot be parameterized in a set of formal, explicit decision rules. Judgment, as described by Knight, is distinct from boldness, innovation, alertness, and leadership. Judgment must be exercised in mundane circumstances, for ongoing operations as well as new ventures. Alertness is the ability to react to existing opportunities while judgment refers to beliefs about new opportunities. Those who specialize in judgmental decision making may be dynamic, charismatic leaders, but they need not possess these traits. In short, in this view, decision making under uncertainty is entrepreneurial, whether it involves imagination, creativity, leadership, and related factors or not.

In the most general sense, then, all human behavior in the world envisioned by Austrian economics is entrepreneurial. For explaining the emergence of firms, however, it is useful to focus on a narrower conception of entrepreneurship, that of a businessperson who invests financial and physical resources in hopes of earning monetary profits and avoiding monetary losses. As outlined earlier, in the Austrian world, production involves a series of temporally specific, causally linked stages and a complex latticework of inputs and intermediate outputs. The heterogeneous capital goods implied by this view of the world, render finding the optimal combination a daunting task (Lachmann, 1956). Contrary to the alertness or the cognitive leadership conceptions, Mises, Hayek, and Rothbard conceive the entrepreneurial function as judgmental decision making under Knightian uncertainty and presupposing the ownership of assets (Salerno, 2008). Consequently, they define the firm as the entrepreneur plus the alienable resources the entrepreneur owns (or is able to influence). An important argument for following 
the Mises-Hayek-Rothbard conception of entrepreneurship lies in the particular nature of judgment. As noted above, Knight (1921) argued that entrepreneurial judgment is not a "normal" factor of production and cannot be bought and sold on a market. While Coase (1937) disagrees, he seems to have overlooked Knight's (1921) key point, namely that while much can be "imagined," the "system where all advice or knowledge was bought as required" (Coase, 1937: 249) cannot include entrepreneurial judgment —in particular the judgment of whether to follow (or not) the recommendations of the advisers (Foss, 1996).

Whereas Kirzner's notion of entrepreneurship as alertness is attractive as it seems to correspond with the intuitive idea that new opportunities need to be discovered, and Witt's idea of entrepreneurship as cognitive leadership is appealing to the undoubtedly important question of how the entrepreneur can exploit (new) business opportunities, the notion of entrepreneurship as judgment following Mises and Hayek seems particularly adept for developing a coherent Austrian theory of the firm.

First, judgment as opposed to alertness cannot be bought and sold on a market. Costs of moral hazard or of trying to communicate entrepreneurial judgments close markets for judgments, for the same reason that judgment is uninsurable (Foss and Klein, 2012). Second, starting with entrepreneurship as judgment as the foundation of a theory of the firm as opposed to cognitive leadership does not per se require resorting to building on a combination of insights from economics, psychology, and sociology. It can, as already roughly illustrated (and as we shall demonstrate in more detail in the subsequent parts) serve to build a theory of the firm purely relying on insights from economics. In particular, the key foundations of a judgmentbased theory of the firm can be grounded within a single theory - namely, in Austrian capital theory. A judgment-based approach thus, while not necessarily entirely circumventing them, 
certainly facilitates reducing dangers of potential misfit of insights as compared to approaches that draw on insights generated in different disciplines.

\section{A JUDGMENT-BASED POSITIVE THEORY}

Why do firms exist, what determines their boundaries, and how are they organized internally? The judgment-based perspective on entrepreneurship associated with Knight and Mises provides several answers. ${ }^{9}$.

\section{The One-Person Firm}

Foss and Klein (2012) argue that the single-person firm can be explained by incomplete markets for judgment: First, entrepreneurs know themselves and their project ideas to be "good risks," but may be unable to communicate this to the capital markets. Second, as emphasized by Knight (1921: 311) and Mises (1949: 585), entrepreneurship represents judgment under "genuine" uncertainty that cannot be assessed in terms of its marginal product and which cannot, accordingly, be paid a wage. In other words, there is no market for the judgment that entrepreneurs rely on, and therefore exercising judgment requires the person with judgment to start a firm. Both reasons imply incomplete markets for judgment and help understand the oneperson firm, yet it does not yet explain multi-person firms (Foss and Klein, 2012). But, it does underscore that entrepreneurs in almost all real-world cases cannot be of the Kirznerian penniless type (Salerno, 2008): Exercising judgment implies, as Klein, (1999) and Foss and Klein (2012) further explain, asset ownership, for judgmental decision-making is ultimately decision-making about the employment of resources, that is: to arrange or organize the capital goods the entrepreneur owns (or has influence over). Obtaining ownership rights over tangible and

\footnotetext{
${ }^{9}$ See also Casson (1982), Rothbard (1985), Salerno (1990, 2008), Langlois and Cosgel (1993).
} 
intangible assets also strengthens the bargaining position. Ownership rights - as stressed in organizational economics — allow parties to "fill in the blanks" of a contract, including the right to exclude others from accessing or using an asset (Foss and Klein, 2012). It thus also ensures that the entrepreneur can appropriate rents from his/her entrepreneurial idea.

\section{The Multi-Person Firm}

Following Lachmann (1956), it may be difficult for the entrepreneur to specify all valued dimensions of assets prior to specialization. Many dimensions or attributes of dimensions (valued and non-valued ones) only become apparent from using, that is: experimenting with the uses of assets and discovering the best uses for them. Given the interdependence that typically exists in a multi-state value chain and involving different inputs, the best time and place to use a particular asset depend on the specification of the uses of all other assets that are needed in value delivery (Hayek, 1941). Thus, entrepreneurs need a contractual set up that allows them to experiment at low cost. Here, Foss and Klein (2012) argue (albeit based rather on mainstream Williamsonian economics than on $\mathrm{AE}$ ) that relying on a hierarchical relationship within an organization as means of coordination instead of the market can be the least costly way for an entrepreneur to organize the experimental activity. Under market contracting collaborators can veto changes in the experimental set-up, thereby extracting additional quasi-rents from other collaborators in return for their "d'accord" to a re-arranged set-up. By possessing the rights to redefine and reallocate decision rights among collaborators (i.e. employees) and to sanction those who do not use their decision rights efficiently, the entrepreneur can conduct experiments without continuously having to renegotiate contracts, thereby saving bargaining and drafting costs (Foss and Klein, 2012). This provides a rational for the multi-person firm within an entrepreneurial judgment approach. 


\section{Efficient Firm Boundaries ${ }^{10}$}

The entrepreneur's success in experimenting with assets, however, does not only depend on his authority to rearrange them, but also on his ability to anticipate future prices and market conditions in order to make rational decisions and to avoid pure "trial and error" processes. Such judgment however relies on information: Economic calculation that allows forming a rational judgment implies the use of today's prices and anticipated future prices to compare present costs with expected future revenues (Klein, 1999). Since entrepreneurs often face a plethora of options, Mises (1951: 110) stressed that "[t]he business of the entrepreneur is not merely to experiment with new technological methods, but to select from the multitude of technologically feasible methods those which are best fit to supply the public in the cheapest way with the things they are asking for most urgently". And it is exactly this need for decision-making under genuine uncertainty that was at the heart of the socialist calculation debate waged by the Austrians in the 1920s and 30s and that provides important insights into the boundaries of the firm (Foss and Klein, 2012; Klein, 1996; Montias, 1976; Rothbard, 1962, 1976; Williamson, 1991).

The Austrian argument against (market) socialism was three-fold (Boettke, 2001): (a) In the absence of private property of the means of production, there will be no market for these means; (b) without such a market, there will be no monetary prices established for the means of production; and (c) without such prices, decision-makers are unable to rationally allocate resources as they lack information that reflects the relative scarcity of resources. Yet, as already Rothbard (1976: 75) notes: "[F]or what the Mises theory focuses on is not simply the numerous

\footnotetext{
${ }^{10}$ Santos and Eisenhardt (2005) propose a number of views on organizational boundaries comprising efficiency, power, competence, and identity perspectives. The Austrian insights from the socialist calculation debate follow efficiency considerations and - in particular in Rothbard's generalization - focus on the question of organizations versus markets. The other perspectives advanced by Santos and Eisenhardt (2005) in contrast focus on nonefficiency oriented questions of conscious versus unconscious organizations, the possession of competences versus their deployment, and ownership versus control, and thus are only limitedly related to the "organizations" versus "markets" debate.
} 
inefficiencies of the political as compared to the profit-making process, but the fact that a market for capital goods has disappeared. This means that, just as socialist central planning could not calculate economically, no One Big Firm could own or control the entire economy."

Within the judgment-based approach to the firm, Foss and Klein (2012) suggest applying insights from the calculation debate-in particular, Rothbard's (1962) generalization to nonsocialist settings - to the discussion about the boundaries of the firm. In any situation, socialist or not, in which no such prices are available, entrepreneurs cannot arrive at rational judgments about the scarcity of the resources and whether an entrepreneurial profit exists (Rothbard, 1962; 1976; Foss and Klein, 2012).

Of course, entrepreneurs might try to infer what prices for these resources would be if there were a functioning market through relying on cost-based estimation techniques, yet such "prices" will under all likelihood diverge from the prices an entrepreneur would observe in a market (Rothbard, 1962). While the past decades have seen many advances in allocating costs and calculating meaningful transfer prices by scholars in economics and management accounting, all the alternative methods developed share the fundamental problem that any such artificial price contains less information than an actual market price (Rothbard, 1962). Therefore, the use of internally traded intermediate goods or services for which no external market reference is available introduces distortions that reduce organizational efficiency. This problem grows as the firm expands and more and more external markets disappear, which means that the "islands of noncalculable chaos swell to proportions of masses and continents" (Rothbard, 1962: 548).

The Austrian ideas developed in the calculation debate therefore suggest that when organizations are large enough to conduct activities that are exclusively internal - so that no reference to the outside market is available - they will face a calculation problem (besides any 
incentive problems that are linked to the fact that managers lacking ultimate property rights have only limited incentive to engage in high effort) (Foss, 2002; Klein, 1996; Rothbard, 1962; Foss and Klein, 2012).

\section{Internal Organization}

Austrians are quick to point out that the key challenge besides incentive issues to internal organization from an Austrian perspective stems from the entrepreneur allocating resources inside the organization typically lacking information or knowledge to make optimal decisions (Mises, 1936; Hayek, 1937; 1973). The fact that firms exist and thrive would seem to indicate that they however somehow successfully cope with this dispersed knowledge.

Foss, Foss, Klein, and Klein (2007) and Foss and Klein (2012) point to Mises (1949) for an answer to this puzzle: He suggests delegation of decision rights to managers - creating what Foss, Foss, and Klein (1997) termed "proxy-entrepreneurs" exercising "derived judgment" as a solution. By delegating decision-making authority to those who "know best," the firm is able to exploit the locally held knowledge without having to codify it for internal communication or motivating managers to explicitly share their knowledge. Yet, Mises (1949) also realized that delegation is a somewhat two-edge sword. Unlike independent players in markets, managers within firms never possess ultimate decision rights and thus there are incentive limits to the extent to which market principles can be applied within firms (Foss, 2002). ${ }^{11}$ This gives rise to problems of motivation, i.e. moral hazard - to use the organizational economics terminology. Managers and employees may use the delegated decision-rights in both productive, that is, functional or value-enhancing from the owners' perspective, and destructive (i.e. dysfunctional

\footnotetext{
${ }^{11}$ Research within the contractual theory of the firm has clarified in the meantime that the problem may be handled if the central (planning) board can credibly commit to a non-interference policy. Committing to a non-interference policy is difficult though in practice, as promises not to intervene for bad cause are simply not credible (Williamson, 1996).
} 
or value-diminishing) ways (Foss, Foss and Klein, 1997; Foss and Klein, 2012). They may pursue new profitable business opportunities or engage in developing new forms of exploiting (quasi)-rents from the firm by creating new forms of hold-ups etc (ibid.). Yet, delegation may also imply risks of duplication of effort due to a lack of coordination of activities. The benefits of delegation in terms of better utilizing dispersed knowledge thus need to be balanced against the costs of delegation due to problems of interest alignment (what organizational economics would call "agency costs") and coordination (Foss, 2002).

Entrepreneurial judgment enters the picture here, as entrepreneurs exercise judgment about other people's judgment. Entrepreneurs evaluate employees according to their ability to use delegated decision rights properly. While this is an attractive answer, it however raises the question of about the actual mechanisms for judging others' judgment (Foss and Klein, 2012). Here, existing Austrian literature is, as Foss and Kein (2012) note, not very forthcoming and allows only speculating about the actual mechanisms implied by Mises and Lachmann.

\section{CONCLUSION}

Many of the analytical components that are necessary to develop a coherent theory of the firm were already present in AE long before they attracted interest within modern organizational economics. Like their neoclassical counterparts Austrians have been reluctant for many years to open up the "black box" of the organization.

In recent years, however, a number of scholars have ventured into developing elements of a distinctly Austrian theory of the firm. In fact, some 75 years after the publication of Coase's (1937) article about the nature of firms and 50 years after Rothbard's (1962) generalization of Mises' argumentation regarding the calculation problem of socialist economies to large firms, Austrians are a good way on to developing a first cast of a distinctly Austrian theory of the firm. 
While some scholars have taken Kirzner's notion of entrepreneurship as alertness as a point for departure of their efforts in building an Austrian theory of the firm, entrepreneurship understood in the Knight-Mises conception of judgment under uncertainty seems particularly promising for such a venture. A judgment-based approach to entrepreneurship allows drawing on Austrian production and capital theory - a unique and coherent theory of capital that allows overcoming major shortcomings of existing (contractual) approaches to the theory of the firm in mainstream organizational economics. The multi-stage nature of production processes gives rise to heterogeneous capital assets, which in turn require entrepreneurs to experiment with capital goods in order to step-by-step discover their attributes. Asset ownership greatly facilitates such experimentation with assets. Thus the Austrian conception of production processes allows deriving why entrepreneurs will not be of the penniless type claimed by Kirzner. Moreover, entrepreneurs cannot sell their judgment on a market, as in a world of thoroughgoing subjectivism as assumed by modern Austrian capital theory, costs of moral hazard or of trying to communicate entrepreneurial judgments close markets for judgments, for the same reason that judgment is uninsurable (Foss and Klein, 2012). Therefore, they need to found their own firm. Heterogeneity in capital goods however also allows explaining the multi-person firm, as a hierarchical relationship (i.e. employment contracts with collaborators) facilitates re-arranging the experimental set-up. The Austrian conception of the production process equally allows explaining firm boundaries by the entrepreneurs' need for indications of relative scarcity of heterogeneous capital goods in order to economically evaluate alternative plans for using capital goods (e.g., Powell, 2010). Finally, the judgment-based approach also allows shedding light on questions of internal organization; entrepreneurs exercise judgment also about other people's judgment. 
However, the judgment approach relies heavily on ideas about the decomposability of processes and asset specificity from more mainstream organizational economics to get from a single-person firm to the multi-person firm. Thus, if one wants to define a firm like in the Coasian theory of the firm - that is: as an employment relationship - Austrian insights available in literature only go part of the road to build a theory of the firm. Similarly, the Austrian idea of the entrepreneur judging others' judgment is still abstract and calls for further refinement. Yet, given the growing proportion of fixed or indirect costs in many (though not all) industries, the calculation problem stressed within the judgment approach advocated by Foss and Klein (2012), however, seems increasingly attractive for empirical and conceptual investigations into organization size. Firms within a particular industry that are better able to allocate fixed and/or indirect costs to the respective subunits within the value chain should be at an advantage in comparison to their peers, and thus both be able to outperform those and to grow larger than them (Klein, 1996). Recent advances in cost accounting, such as activity-based costing (Cooper and Kaplan, 1988) or activity-based budgeting (Brimson and Antos, 1999) may provide more accurate approximations in transfer pricing and thus reduce the misallocations and inefficiencies linked to the disappearance of markets. Yet, it is unclear so far whether and how much the introduction of such systems allows a firm to shift outwards its limits and how they affect relative performance of firms.

Thus, while a judgment-based approach to the theory of the firm based on Austrian capital theory without any doubt still needs further refinement, it addresses major weaknesses in the assumptions underlying the dominant (contractual) theory of the firm in organizational economics. It thus promises to be a fruitful avenue for arriving at a "better" theory of the firm. 
Yet, Austrians might not want to stop there. It also seems time to broaden the study from firms to organizations, that is, i.e. to build a first version of a "theory of the organization". While all organizations face uncertainty and while it is likely that all organizations plan in one form or the other, and thus the calculation problem might apply to all kinds of private, public, profit or non-profit organizations (Klein, 1996), more research explicitly targeting not-for-profit organizations seems necessary to establish the generalizability of the insights from firms to all kinds of organizations.

\section{REFERENCES}

Alchian, Armen A. and Harold Demsetz. 1972. "Production, Information Costs, and Economic Organization", American Economic Review 62 (December): 777-95.

Argyres, Nicholas, Teppo Felin, Nicolai Foss, and Todd Zenger. 2012."The Organizational Economics of Organizational Capability: a Research Agenda”. Organization Science 23: 1213-1226 (2012).

Boettke, Peter J. 2001. "Economic Calculation: The Austrian Contribution to Political Economy," in Peter J. Boettke (ed.), Calculation and Coordination (pp. 29-46). London: Routledge.

Brimson, James A. and John Antos 1999. Driving Value using Activity-Based Budgeting. New York: Wiley.

Bylund, Per L. 2011. "The Division of Labor and the Firm: An Austrian Attempt at Explaining the Firm in the Market." Quarterly Journal of Austrian Economics 14: 188-215.

Casson, Mark. 2000. "An Entrepreneurial Theory of the Firm," in: Nicolai J. Foss and Volker Mahnke (eds.), Competence, Governance and Entrepreneurship: Advances in Economic Strategy Research (pp. 116-145). New York: Oxford University Press.

Coase, Ronald H. 1937. “The Nature of the Firm,” Economica 4: 386-405.

Coase, Ronald H. 1988. "The Nature of the Firm: Origin," Journal of Law, Economics and Organization 4: 3-17.

Cool, K. and Dan Schendel 1988. "Performance Differences among Strategic Group Members," Strategic Management Journal 9: 207-223.Cooper, Robin and Robert S. Kaplan 1988. "Measure Costs Right: Make the Right Decisions," Harvard Business Review 66: 96-103.

Demsetz, Harold. 1967. "Toward a Theory of Property Rights," American Economic Review 57(2): 347-359. In idem. 1988, Ownership, Control, and the Firm. Oxford: Basil Blackwell.

Demsetz, Harold. 1988. "The Theory of the Firm Revisited," Journal of Law, Economics and Organization 4: 141-162. 
Dulbecco, Philippe and Pierre Garrouste. 1999. "Towards an Austrian Theory of the Firm," Review of Austrian Economics 12: 43-64.

Foss, Kirsten, Nicolai J. Foss, Peter G. Klein and Sandra Klein. 2007. "The Entrepreneurial Organization of Heterogeneous Capital," Journal of Management Studies 44(7): 11651186.

Foss, Kirsten, Nicolai J. Foss, and Peter G. Klein 2007. "Original and Derived Judgment: An Entrepreneurial Theory of Economic Organization," Organization Studies 28(12):18931912.

Foss, Nicolai J. 1994. "Austrian Economics and Neo-institutionalism: the case of the Theory of the Firm," in: Nicolai J. Foss, ed. 1994, The Austrian School and Modern Economics (pp. 149-179). Copenhagen: Handelshojskølens Forlag.

Foss, Nicolai J. 1996. “The 'Alternative' Theories of Knight and Coase, and the Modern Theory of the Firm," Journal of the History of Economic Thought 18: 76-95.

Foss, Nicolai J. 1997. "Austrian Insights and the Theory of the Firm." Advances in Austrian Economics 4: 175-198.

Foss, Nicolai J. 2002. "Coase vs. Hayek: Economic Organization and the Knowledge Economy," International Journal of the Economics of Business 9(1): 9-35.

Foss, Nicolai J., and Peter G. Klein. 2010. "Austrian Economics and the Theory of the Firm," in Peter G. Klein and Michael E. Sykuta, eds., The Elgar Companion to Transaction Cost Economics (Cheltenham, U.K.: Edward Elgar, 2010), pp. 263-272.

Foss, Nicolai J., and Peter G. Klein. 2012. Organizing Entrepreneurial Judgment: A New Approach to the Firm. Cambridge: Cambridge University Press.

Foss, Nicolai J., and Peter G. Klein. 2013. "Hayek and Organizational Studies," forthcoming in: Paul Adler, Paul du Gay, Glenn Morgan, and Mike Reed, eds. Oxford Handbook of Sociology, Social Theory and Organization Studies: Contemporary Currents. Oxford: Oxford University Press.

Gibbons, Robert, and John Roberts. 2012. Handbook of Organizational Economics. Princeton: Princeton University Press.

Grossman, Sanford and Oliver Hart. 1986. "The Costs and the Benefits of Ownership: A Theory of Vertical Integration," Journal of Political Economy 94: 691-719.

James, Harvey S., Jr., Peter G. Klein, and Michael E. Sykuta. 2011. "The Adoption, Diffusion, and Evolution of Organizational Form," Managerial and Decision Economics 32: 243-59.

Hayek, Friedrich A. 1931. Prices and Production. London: George Routledge and Sons.

Hayek, Friedrich A. 1933b. "Trend of Economic Thinking," Economica 13: 121-137.

Hayek, Friedrich A. 1935b. Collectivist Economic Planning. London: Routledge.

Hayek, Friedrich A. 1937. "Economics and Knowledge", Economica, new series 4: 33-54, reprinted in Hayek (1948).

Hayek, Friedrich A. 1940. "Socialist Calculation III: the Competitive 'Solution'," Economica, new series 7(26): 125-149, reprinted in Hayek (1948). 
Hayek, Friedrich A. 1941. The Pure Theory of Capital. London: George Routledge \& Sons.

Hayek, Friedrich A. 1945. "The Use of Knowledge in Society", American Economic Review 35(4): 519-530, reprinted in Hayek (1948).

Hayek, Friedrich A. 1948. Individualism and economic order. Chicago, IL: The University of Chicago Press.

Hayek, Friedrich A. 1973. Law, Legislation and Liberty, Vol. 1: Rules and Order. Chicago, IL: University of Chicago Press.

Holmström, B. 1979. Moral hazard and observability. Bell Journal of Economics, 10: 74-91.

Holmstrom, B. \& Milgrom, P. 1991. Multitask principal agent analyses: Incentive contracts, asset ownership and job design. Journal of Law, Economics and Organization, 7: 24-52.

Iaonnides, Stavros 1998. "Towards an Austrian Perspective on the Firm," Review of Austrian Economics 11: 77-97.

Jensen Michael and William H. Meckling 1976. "Theory of the Firm: Managerial Behavior, Agency Costs, and Capital Structure," Journal of Financial Economics 3 (October): 305360.

Jacobides, Michael G. and Sidney G. Winter. 2005. "The Co-Evoluation of Capabilities and Transaction Costs: Explaining the Institutional Structure of Production," Strategic Management Journal, 26(5): 395-413.

Kirzner, Israel M. 1973. Competition and Entrepreneurship. Chicago: University of Chicago Press.

Klein, Peter G. 1996. "Economic Calculation and the Limits of Organization," Review of Austrian Economics 9(2): 3-28.

Klein, Peter G. 1999. "Entrepreneurship and Corporate Governance," Quarterly Journal of Austrian Economics 2(2): 19-42.

Klein, Peter G., and Sandra K. Klein 2001, "Do Entrepreneurs Make Predictable Mistakes? Evidence from Corporate Divestitures," Quarterly Journal of Austrian Economics 4: 3-25.

Knight, Frank H. 1921. Risk, Uncertainty and Profit. Boston: Houghton Mifflin Company.

Lachmann, Ludwig M. 1956. Capital and Its Structure. Kansas City: Sheed Andrews and McMeel, 1978.

Lachmann, Ludwig M. 1986. The market as an economic process. Oxford, U.K.: Blackwell.

Langlois, Richard N. 1992. "Orders and Organizations: Toward an Austrian Theory of ocial Institutions", in: Bruce J. Caldwell and Stephan Boehm, eds., Austrian Economics: Tensions and New Directions (pp. 165-183). Boston and Dordrecht: Kluwer Academic Publishers.

Langlois, Richard N. 1995. “Do Firms Plan?” Constitutional Political Economy 6: 247-261.

Langlois, Richard N. 1998. "Capabilities and the Theory of the Firm," in: Nicolai J. Foss and Brian J. Loasby (eds.), Capabilities, Coordination, and Economic Organization: Essays in Honor of George B Richardson (pp. 182-203). London: Routledge. 
Langlois, Richard N. 2012. "The Austrian Theory of the Firm: Retrospect and Prospect," forthcoming in: Review of Austrian Economics, DOI 10.1007/s11138-012-0171-y.

Langlois and Cosgel 1993 [please add the reference]

Langlois, Richard N. and Nicolai J. Foss. 1999. "Capabilities and Governance: The Rebirth of Production in the Theory of Economic Organization," Kyklos 52: 201-218.

Lavoie, Don. 1985. Rivalry and Central Planning: The Socialist Calculation Debate Revisited. Cambridge: Cambridge University Press.

Lewin, Peter and Steven A. Phelan. 2000. "An Austrian Theory of the Firm," Review of Austrian Economics 13: 59-79.

Lien, Lasse B., and Peter G. Klein. 2013. "Can the Survivor Principle Survive Diversification?" Organization Science, forthcoming.

Loasby, Brian J. 1976. Choice, Complexity, and Ignorance. Cambridge: Cambridge University Press.

Loasby, Brian J. 1992. "Market Co-ordination", in: Bruce J. Caldwell and Stephan Boehm, eds., Austrian Economics: Tensions and New Directions (pp. 137-156). Boston and Dordrecht: Kluwer Academic Publishers.

Marchal, Jean 1951. "The Construction of a New Theory of Profit," American Economic Review 41: 549-565.

Menger, Carl 1871. Principles of Economics. New York: New York University Press, Reprint 1976.

Menger, Carl 1883. Investigations into the Method of the Social Sciences, with Special Reference to Economics. Louis Schneider (ed.), Francis J Nock (trans.). New York: New York University Press, 1985.

Mises, Ludwig von 1920. Economic Calculation in the Socialist Commonwealth, Auburn, Ala.: Ludwig von Mises Institute, 1990.

Mises, Ludwig von 1936. Socialism: An economic and sociological Analysis. Indianapolis, IN: Liberty Press, 1981.

Mises, Ludwig von 1944. Bureaucracy. New Haven: Yale University Press.

Mises, Ludwig von 1947. Planned Chaos. Irvington on Hudson, NY: Foundation for Economic Education.

Mises, Ludwig von 1949. Human Action. San Francisco, CA: Fox and Wilkes.

Mises, Ludwig von 1951. "Profit and Loss", in idem., Planning for Freedom (pp. 108-150), $4^{\text {th }}$ edition, Spring Mills, PA: Libertarian Press, 1980.

Monteverde, Kirk 1995. "Technical Dialog as an Incentive for Vertical Integration in the Semiconductor Industry," Management Science 41: 1624-1628.

Montias, J. Michael. 1976. The Structure of Economic Systems. New Haven: Yale University Press. 
Nelson, Richard R. 1991. "Why Do Firms Differ, and How Does it Matter?" Strategic Management Journal 12: 61-74.

O'Driscoll, G. P. and Mario J. Rizzo. 1985. The Economics of Time and Ignorance. Oxford: Basil Blackwell.

Porter, M. E. 1979. “The Structure within Industries and Companies' Performance," Review of Economics and Statistics 61: 214-228.

Ross, S A 1973. "The Economic Theory of Agency: The Principal's Problem", American Economic Review 63(2): 134-39.

Rothbard, Murray N. 1962. Man, Economy, and State: A Treatise on Economic Principles. Princeton, NJ: Van Nostrand.

Rothbard, Murray N. 1970. Power and Market. Los Angeles: Nash Publishing.

Rothbard, Murray N. 1976. Ludwig von Mises and Economic Calcualtion Under Socialism.” In: Laurence S. Moss, ed., The Economics of Ludwig von Mises: Toward a Critical Reappraisal (pp. 67-77). Kansas City: Sheed Andrews and McMeel.

Rothbard, Muarry N. 1985. "Professor Kirzner on Entrepreneurship", Journal of Libertarian Studies 7(2): 281-286.

Salerno, Joseph. 1990. "Ludwig von Mises as a Social Rationalist", The Review of Austrian Economics 4(1): 26-54.

Salerno, Joseph. 2008. "The Entrepreneur: Real and Imagined," Quarterly Journal of Austrian Economics 11: 188-207.

Sautet, Frederic 2010. "The competitive market is a process of entrepreneurial discovery," in: Peter, J. Boettke, ed., Handbook on Contemporary Austrian Economics (pp. 87-108). Cheltenham, UK: Edward Elgar.

Spulber, Dan F. 2009. "Discovering the Role of the Firm: The Separation Criterion and Corporate Law.” Berkeley Business Law Journal 6.

Williamson, Oliver E. 1971. "The Vertical Integration of Production: Market Failure Considerations," American Economic Review 61: 112-123.

Williamson, Oliver E. 1975. Markets and Hierarchies. New York: The Free Press.

Williamson, Oliver E. 1985. The Economic Institutions of Capitalism. New York: The Free Press.

Williamson, Oliver E. 1991. "Economic Institutions: Spontaneous and Intentional Governance," Journal of Law, Economics and Organization 7: 159-187.

Williamson, Oliver E. 1996. "Efficiency, power, authority and economic organization," in J. Groenewegen (ed.), Transaction Cost Economics and Beyond (pp. 11-43). New York, Springer.

Witt, Ulrich 1998. "Imagination and Leadership: the Neglected Dimension of an Evolutionary Theory of the Firm," Journal of Economic Behavior and Organization 35: 161-177.

Witt, Ulrich 1999. “Do Entrepreneurs Need Firms?” Review of Austrian Economics 11: 99-109. 
Witt, Ulrich 2003. "Market Opportunity and Organizational Grind: The Two Sides of Entrepreneurship," Advances in Austrian Economics 6: 131-151.

Witt, Ulrich 2007. "Firms as Realizations of Entrepreneurial Vision," Journal of Management Studies 44(7): 1126-1140. 


\section{SMG - Working Papers \\ www.cbs.dk/smg \\ 2003}

2003-1: Nicolai J. Foss, Kenneth Husted, Snejina Michailova, and Torben Pedersen: Governing Knowledge Processes: Theoretical Foundations and Research Opportunities.

2003-2: Yves Doz, Nicolai J. Foss, Stefanie Lenway, Marjorie Lyles, Silvia Massini, Thomas P. Murtha and Torben Pedersen: Future Frontiers in International Management Research: Innovation, Knowledge Creation, and Change in Multinational Companies.

2003-3: Snejina Michailova and Kate Hutchings: The Impact of In-Groups and OutGroups on Knowledge Sharing in Russia and China CKG Working Paper.

2003-4: Nicolai J. Foss and Torben Pedersen: The MNC as a Knowledge Structure: The Roles of Knowledge Sources and Organizational Instruments in MNC Knowledge Management CKG Working Paper.

2003-5: Kirsten Foss, Nicolai J. Foss and Xosé H. Vázquez-Vicente: “Tying the Manager's Hands": How Firms Can Make Credible Commitments That Make Opportunistic Managerial Intervention Less Likely CKG Working Paper.

2003-6: Marjorie Lyles, Torben Pedersen and Bent Petersen: Knowledge Gaps: The Case of Knowledge about Foreign Entry.

2003-7: Kirsten Foss and Nicolai J. Foss: The Limits to Designed Orders: Authority under "Distributed Knowledge" CKG Working Paper.

2003-8: Jens Gammelgaard and Torben Pedersen: Internal versus External Knowledge Sourcing of Subsidiaries - An Organizational Trade-Off.

2003-9: Kate Hutchings and Snejina Michailova: Facilitating Knowledge Sharing in Russian and Chinese Subsidiaries: The Importance of Groups and Personal Networks Accepted for publication in Journal of Knowledge Management.

2003-10: Volker Mahnke, Torben Pedersen and Markus Verzin: The Impact of Knowledge Management on MNC Subsidiary Performance: the Role of Absorptive Capacity CKG Working Paper.

2003-11: Tomas Hellström and Kenneth Husted: Mapping Knowledge and Intellectual Capital in Academic Environments: A Focus Group Study Accepted for publication in Journal of Intellectual Capital CKG Working Paper.

2003-12: Nicolai J Foss: Cognition and Motivation in the Theory of the Firm: Interaction or "Never the Twain Shall Meet"? Accepted for publication in Journal des Economistes et des Etudes Humaines CKG Working Paper.

2003-13: Dana Minbaeva and Snejina Michailova: Knowledge Transfer and Expatriation Practices in MNCs: The Role of Disseminative Capacity.

2003-14: Christian Vintergaard and Kenneth Husted: Enhancing Selective Capacity Through Venture Bases. 


\section{4}

2004-1: Nicolai J. Foss: Knowledge and Organization in the Theory of the Multinational Corporation: Some Foundational Issues

2004-2: Dana B. Minbaeva: HRM Practices and MNC Knowledge Transfer

2004-3: Bo Bernhard Nielsen and Snejina Michailova: Toward a Phase-Model of Global Knowledge Management Systems in Multinational Corporations

2004-4: Kirsten Foss \& Nicolai J Foss: The Next Step in the Evolution of the RBV: Integration with Transaction Cost Economics

2004-5: Teppo Felin \& Nicolai J. Foss: Methodological Individualism and the Organizational Capabilities Approach

2004-6: Jens Gammelgaard, Kenneth Husted, Snejina Michailova: Knowledge-sharing Behavior and Post-acquisition Integration Failure

2004-7: Jens Gammelgaard: Multinational Exploration of Acquired R\&D Activities

2004-8: Christoph Dörrenbächer \& Jens Gammelgaard: Subsidiary Upgrading? Strategic Inertia in the Development of German-owned Subsidiaries in Hungary

2004-9: Kirsten Foss \& Nicolai J. Foss: Resources and Transaction Costs: How the Economics of Property Rights Furthers the Resource-based View

2004-10: Jens Gammelgaard \& Thomas Ritter: The Knowledge Retrieval Matrix: Codification and Personification as Separate Strategies

2004-11: Nicolai J. Foss \& Peter G. Klein: Entrepreneurship and the Economic Theory of the Firm: Any Gains from Trade?

2004-12: Akshey Gupta \& Snejina Michailova: Knowledge Sharing in Knowledge-Intensive Firms: Opportunities and Limitations of Knowledge Codification

2004-13: Snejina Michailova \& Kate Hutchings: Knowledge Sharing and National Culture: A Comparison Between China and Russia

\section{5}

2005-1: Keld Laursen \& Ammon Salter: My Precious - The Role of Appropriability Strategies in Shaping Innovative Performance

2005-2: Nicolai J. Foss \& Peter G. Klein: The Theory of the Firm and Its Critics: A Stocktaking and Assessment

2005-3: Lars Bo Jeppesen \& Lars Frederiksen: Why Firm-Established User Communities Work for Innovation: The Personal Attributes of Innovative Users in the Case of Computer-Controlled Music

2005-4: Dana B. Minbaeva: Negative Impact of HRM Complementarity on Knowledge Transfer in MNCs

2005-5: Kirsten Foss, Nicolai J. Foss, Peter G. Klein \& Sandra K. Klein: Austrian Capital 
Theory and the Link Between Entrepreneurship and the Theory of the Firm

2005-1: Nicolai J. Foss: The Knowledge Governance Approach

2005-2: Torben J. Andersen: Capital Structure, Environmental Dynamism, Innovation Strategy, and Strategic Risk Management

2005-3: Torben J. Andersen: A Strategic Risk Management Framework for Multinational Enterprise

2005-4: Peter Holdt Christensen: Facilitating Knowledge Sharing: A Conceptual Framework

2005-5 Kirsten Foss \& Nicolai J. Foss: Hands Off! How Organizational Design Can Make Delegation Credible

2005-6 Marjorie A. Lyles, Torben Pedersen \& Bent Petersen: Closing the Knowledge Gap in Foreign Markets - A Learning Perspective

2005-7 Christian Geisler Asmussen, Torben Pedersen \& Bent Petersen: How do we Capture "Global Specialization" when Measuring Firms' Degree of internationalization?

2005-8 Kirsten Foss \& Nicolai J. Foss: Simon on Problem-Solving: Implications for New Organizational Forms

2005-9 Birgitte Grøgaard, Carmine Gioia \& Gabriel R.G. Benito: An Empirical Investigation of the Role of Industry Factors in the Internationalization Patterns of Firms

2005-10 Torben J. Andersen: The Performance and Risk Management Implications of Multinationality: An Industry Perspective

2005-11 Nicolai J. Foss: The Scientific Progress in Strategic Management: The case of the Resource-based view

2005-12 Koen H. Heimeriks: Alliance Capability as a Mediator Between Experience and Alliance Performance: An Empirical Investigation Into the Alliance Capability Development Process

2005-13 Koen H. Heimeriks, Geert Duysters \& Wim Vanhaverbeke: Developing Alliance Capabilities: An Empirical Study

2005-14 JC Spender: Management, Rational or Creative? A Knowledge-Based Discussion

\section{6}

2006-1: Nicolai J. Foss \& Peter G. Klein: The Emergence of the Modern Theory of the Firm

2006-2: Teppo Felin \& Nicolai J. Foss: Individuals and Organizations: Thoughts on a Micro-Foundations Project for Strategic Management and Organizational Analysis

2006-3: Volker Mahnke, Torben Pedersen \& Markus Venzin: Does Knowledge Sharing 
Pay? An MNC Subsidiary Perspective on Knowledge Outflows

2006-4: Torben Pedersen: Determining Factors of Subsidiary Development

2006-5 Ibuki Ishikawa: The Source of Competitive Advantage and Entrepreneurial Judgment in the RBV: Insights from the Austrian School Perspective

2006-6 Nicolai J. Foss \& Ibuki Ishikawa: Towards a Dynamic Resource-Based View: Insights from Austrian Capital and Entrepreneurship Theory

2006-7 Kirsten Foss \& Nicolai J. Foss: Entrepreneurship, Transaction Costs, and Resource Attributes

2006-8 Kirsten Foss, Nicolai J. Foss \& Peter G. Klein: Original and Derived Judgement: An Entrepreneurial Theory of Economic Organization

2006-9 Mia Reinholt: No More Polarization, Please! Towards a More Nuanced Perspective on Motivation in Organizations

2006-10 Angelika Lindstrand, Sara Melen \& Emilia Rovira: Turning social capital into business? A study of Swedish biotech firms' international expansion

2006-11 Christian Geisler Asmussen, Torben Pedersen \& Charles Dhanaraj: Evolution of Subsidiary Competences: Extending the Diamond Network Model

2006-12 John Holt, William R. Purcell, Sidney J. Gray \& Torben Pedersen: Decision Factors Influencing MNEs Regional Headquarters Location Selection Strategies

2006-13 Peter Maskell, Torben Pedersen, Bent Petersen \& Jens Dick-Nielsen: Learning Paths to Offshore Outsourcing - From Cost Reduction to Knowledge Seeking

2006-14 Christian Geisler Asmussen: Local, Regional or Global? Quantifying MNC Geographic Scope

2006-15 Christian Bjørnskov \& Nicolai J. Foss: Economic Freedom and Entrepreneurial Activity: Some Cross-Country Evidence

2006-16 Nicolai J. Foss \& Giampaolo Garzarelli: Institutions as Knowledge Capital: Ludwig M. Lachmann's Interpretative Institutionalism

2006-17 Koen H. Heimriks \& Jeffrey J. Reuer: How to Build Alliance Capabilities

2006-18 Nicolai J. Foss, Peter G. Klein, Yasemin Y. Kor \& Joseph T. Mahoney: Entrepreneurship, Subjectivism, and the Resource - Based View: Towards a New Synthesis

2006-19 Steven Globerman \& Bo B. Nielsen: Equity Versus Non-Equity International Strategic Alliances: The Role of Host Country Governance

\section{7}

2007-1 Peter Abell, Teppo Felin \& Nicolai J. Foss: Building Micro-Foundations for the Routines, Capabilities, and Performance Links 
2007-2 Michael W. Hansen, Torben Pedersen \& Bent Petersen: MNC Strategies and Linkage Effects in Developing Countries

2007-3 Niron Hashai, Christian G. Asmussen, Gabriel R.G. Benito \& Bent Petersen: Predicting the Diversity of Foreign Entry Modes

2007-4 Peter D. Ørberg Jensen \& Torben Pedersen: Whether and What to Offshore?

2007-5 Ram Mudambi \& Torben Pedersen: Agency Theory and Resource Dependency Theory: Complementary Explanations for Subsidiary Power in Multinational Corporations

2007-6 Nicolai J. Foss: Strategic Belief Management

2007-7 Nicolai J. Foss: Theory of Science Perspectives on Strategic Management Research: Debates and a Novel View

2007-8 Dana B. Minbaeva: HRM Practices and Knowledge Transfer in MNCs

2007-9 Nicolai J. Foss: Knowledge Governance in a Dynamic Global Context: The Center for Strategic Management and Globalization at the Copenhagen Business School

2007-10 Paola Gritti \& Nicolai J. Foss: Customer Satisfaction and Competencies: An Econometric Study of an Italian Bank

2007-11 Nicolai J. Foss \& Peter G. Klein: Organizational Governance

2007-12 Torben Juul Andersen \& Bo Bernhard Nielsen: The Effective Ambidextrous Organization: A Model of Integrative Strategy Making Processes.

\section{8}

2008-1 Kirsten Foss \& Nicolai J. Foss: Managerial Authority When Knowledge is Distributed: A Knowledge Governance Perspective

2008-2 Nicolai J. Foss: Human Capital and Transaction Cost Economics.

2008-3 Nicolai J. Foss \& Peter G. Klein: Entrepreneurship and Heterogeneous Capital.

2008-4 Nicolai J. Foss \& Peter G. Klein: The Need for an Entrepreneurial Theory of the Firm.

2008-5 Nicolai J. Foss \& Peter G. Klein: Entrepreneurship: From Opportunity Discovery to Judgment.

2008-6 Mie Harder: How do Rewards and Management Styles Influence the Motivation to Share Knowledge?

2008-7 Bent Petersen, Lawrence S. Welch \& Gabriel R.G. Benito: Managing the Internalisation Process - A Theoretical Perspective.

2008-8 Torben Juul Andersen: Multinational Performance and Risk Management Effects: Capital Structure Contingencies. 
2008-9 Bo Bernard Nielsen: Strategic Fit and the Role of Contractual and Procedural Governance in Alliances: A Dynamic Perspective.

2008-10 Line Gry Knudsen \& Bo Bernhard Nielsen: Collaborative Capability in R\&D Alliances: Exploring the Link between Organizational and Individual level Factors.

2008-11 Torben Juul Andersen \& Mahesh P. Joshi: Strategic Orientations of Internationalizing Firms: A Comparative Analysis of Firms Operating in Technology Intensive and Common Goods Industries.

2008-12 Dana Minbaeva: HRM Practices Affecting Extrinsic and Intrinsic Motivation of Knowledge Receivers and their Effect on Intra-MNC Knowledge Transfer.

2008-13 Steen E. Navrbjerg \& Dana Minbaeva: HRM and IR in Multinational Corporations: Uneasy Bedfellows?

2008-14 Kirsten Foss \& Nicolai J. Foss: Hayekian Knowledge Problems in Organizational Theory.

2008-15 Torben Juul Andersen: Multinational Performance Relationships and Industry Context.

2008-16 Larissa Rabbiosi: The Impact of Subsidiary Autonomy on MNE Knowledge Transfer: Resolving the Debate.

2008-17 Line Gry Knudsen \& Bo Bernhard Nielsen: Organizational and Individual Level Antecedents of Procedural Governance in Knowledge Sharing Alliances.

2008-18 Kirsten Foss \& Nicolai J. Foss: Understanding Opportunity Discovery and Sustainable Advantage: The Role of Transaction Costs and Property Rights.

2008-19 Teppo Felin \& Nicolai J. Foss: Social Reality, The Boundaries of Self-fulfilling Prophecy, and Economics.

2008-20 Yves Dos, Nicolai J. Foss \& José Santos: A Knowledge System Approach to the Multinational Company: Conceptual Grounding and Implications for Research

2008-21 Sabina Nielsen \& Bo Bernhard Nielsen: Why do Firms Employ foreigners on Their Top Management Teams? A Multi-Level Exploration of Individual and Firm Level Antecedents

2008-22 Nicolai J. Foss: Review of Anders Christian Hansen's “Uden for hovedstrømmen - Alternative strømninger i økonomisk teori"

2008-23 Nicolai J. Foss: Knowledge, Economic Organization, and Property Rights

2008-24 Sjoerd Beugelsdijk, Torben Pedersen \& Bent Petersen: Is There a Trend Towards Global Value Chain Specialization? - An Examination of Cross Border Sales of US Foreign Affiliates 
2008-25 Vikas Kumar, Torben Pedersen \& Alessandro Zattoni: The performance of business group firms during institutional transition: A longtitudinal study of Indian firms

2008-26 Sabina Nielsen \& Bo B. Nielsen: The effects of TMT and Board Nationality Diversity and Compensation on Firm Performance

2008-27 Bo B. Nielsen \& Sabina Nielsen: International Diversification Strategy and Firm Performance: A Multi-Level Analysis of Firm and Home Country Effects

\section{9}

2009-1 Nicolai J. Foss: Alternative Research Strategies in the Knowledge Movement: From Macro Bias to Micro-Foundations and Multi-Level Explanation

2009-2 Nicolai J. Foss \& Peter G. Klein: Entrepreneurial Alertness and Opportunity Discovery: Origins, Attributes, Critique

2009-3 Nicolai J. Foss \& Dana B. Minbaeva: Governing Knowledge: The Strategic Human Resource Management Dimension

2009-4 Nils Stieglitz \& Nicolai J. Foss: Opportunities and New Business Models: Transaction Cost and Property Rights Perspectives on Entrepreneurships

2009-5 Torben Pedersen: Vestas Wind Systems A/S: Exploiting Global R\&D Synergies

2009-6 Rajshree Agarwal, Jay B. Barney, Nicolai J. Foss \& Peter G. Klein: Heterogeneous Resources and the Financial Crisis: Implications of Strategic Management Theory

2009-7 Jasper J. Hotho: A Measure of Comparative Institutional Distance

2009-8 Bo B. Nielsen \& Sabina Nielsen: The Impact of Top Management Team Nationality Diversity and International Experience on Foreign Entry Mode

2009-9 Teppo Felin \& Nicolai Juul Foss: Experience and Repetition as Antecedents of Organizational Routines and Capabilities: A Critique of Behaviorist and Empiricist Approaches

2009-10 Henk W. Volberda, Nicolai J. Foss \& Marjorie E. Lyles: Absorbing the Concept of Absorptive Capacity: How To Realize Its Potential in the Organization Field

2009-11 Jan Stentoft Arlbjørn, Brian Vejrum Wæhrens, John Johansen \& Torben Pedersen: Produktion i Danmark eller offshoring/outsourcing: Ledelsesmæssige udfordringer 


\section{0}

2010-1 Dana B. Minbaeva, Kristiina Mäkelä \& Larissa Rabbiosi: Explaining Intraorganizational Knowledge Transfer at the Individual Level

2010-2 Dana B.Minbaeva \& Torben Pedersen: Governing Individual Knowledge Sharing Behavior

2010-3 Nicolai J. Foss \& Peter G. Klein: Alertness, Judgment, and the Antecedents of Entrepreneurship

2010-4 Nicolai J.Foss \& Joseph T.Mahoney: Exploring Knowledge Governance

2010-5 Jasper J. Hotho, Florian Becker-Ritterspach \& Ayse Saka-Helmhout: Enriching Absorptive Capacity Through Social Interaction

2010-6 Nicolai J. Foss \& Bo B. Nielsen: Researching Collaborative Advantage: Some Conceptual and Multi-level Issues

2010-7 Nicolai J. Foss \& Nils Stieglitz: Modern Resource-Based Theory(ies)

2010-8 Christian Bjørnskov \& Nicolai J. Foss: Do Economic Freedom and Entrepreneurship Impact Total Factor Productivity?

2010-9 Gabriel R.G. Benito, Bent Petersen \& Lawrence S. Welch: Mode Combinations and International Operations: Theoretical Issues and an Empirical Investigation

\section{1}

2011-1 Peter D. Ørberg Jensen \& Bent Petersen: Human Asset Internalization and Global Sourcing of Services - A Strategic Management Analysis on Activity-level

2011-2 Mie Harder: Management Innovation Capabilities: A Typology and Propositions for Management Innovation Research

2011-3 Mie Harder: Internal Antecedents of Management Innovation: The effect of diagnostic capability and implementation capability 
2011-4 Mie Harder: Explaining Management Innovation Pervasiveness: The Role of Internal Antecedents

2011-5 Mie Harder: Internal Determinants of Product Innovation and Management Innovation: The Effect of Diagnostic Capability and Implementation Capability

2011-6 Nicolai J. Foss, Peter G. Klein \& Per L. Bylund: Entrepreneurship and the Economics of the Firm

2011-7 Nicolai J. Foss \& Jacob Lyngsie: The Emerging Strategic Entrepreneurship Field: Origins, Key Tenets and Research Gaps

2011-8 Nicolai J. Foss: Entrepreneurship in the Context of the Resource-based View of the Firm

2011-9 Bent Petersen, Gabriel R.G. Benito, Olesya Dovgan \& Lawrence Welch: Offshore outsourcing: A dynamic, operation mode perspective

2011-10 Bent Petersen, Gabriel R. G. Benito \& Lawrence Welch: Dynamics of Foreign Operation Modes and their Combinations: Insights for International Strategic Management

2011-11 Nicolai J. Foss: Teams, Team Motivation, and the Theory of the Firm

2011-12 Nicolai J. Foss: Knowledge Governance: Meaning, Nature, Origins, and Implications

2011-13 Nicolai J. Foss, Kirsten Foss \& Phillip C. Nell: MNC Organizational Form and Subsidiary Motivation Problems: Controlling Intervention Hazards in the Network MNC

2011-14 Kåre Moberg: Evaluating Content Dimensions in Entrepreneurship Education

\section{2}

2012-1 Nicolai J. Foss, Nicholas Argyres, Teppo Felin \& Todd Zenger: The Organizational Economics of Organizational Capability and Heterogeneity: A Research Agenda 
2012-2 Torben J. Andersen, Carina Antonia Hallin \& Sigbjørn Tveterås: A Prediction Contest: The Sensing of Frontline Employees Against Executive Expectations

2012-3 Peter G. Klein, Jay B. Barney \& Nicolai J. Foss: Strategic Entrepreneurship

2012-4 Kåre Moberg: The Impact of Entrepreneurship Education and Project-based Education on Students' Personal Development and Entrepreneurial Intentions at the Lower Levels of the Educational System: Too Much of Two Good Things?

2012-5 Keld Laursen \& Nicolai J. Foss: Human Resource Management Practices and Innovation

2012-6 Kåre Moberg: An Entrepreneurial Self-Efficacy Scale with a Neutral Wording

\section{3}

2013-1

Nicolai J. Foss, Diego Stea: The Principal's Theory of Mind: The Role of Mentalizing for Reward Design and Management in Principal-Agent Relations

2013-2 Dana Minbaeva, Chansoo Park \& Ilan Vertinsky: The Influence of Foreign Partners' Disseminative Capacities on Knowledge Transfers to International Joint Ventures

2013-3

Nicolai J. Foss \& Peter G. Klein: Hayek and Organizational Studies

2013-4 Kåre Moberg, Lene Vestergaard, Casper Jørgensen, Elisabeth Markussen \& Sose Hakverdyan: How to Assess the Development of Entrepreneurship Education at University Level - the Case of Denmark

2013-5 Nicolai J. Foss \& Siegwart Lindenberg: Micro-Foundations For Strategy: A Goal-Framing Perspective on the Drivers of Value Creation 
2013-6 Nicolai J. Foss, Jacob Lyngsie \& Shaker A. Zahra: The Role of External Knowledge Sources and Organizational Design in the Process of Opportunity Exploitation

2013-7 Stefan Linder \& Nicolai J. Foss: Agency Theory.

2013-8 Nicolai J. Foss, Peter G. Klein, Stefan Linder: Organizations and Markets 